\title{
A Study of Community Entrepreneurship Development Research: A Resource of Clarification and Forecast
}

\author{
J Jose Prabhu
}

Research Associate, International Centre for Entrepreneurship Learning \& Research, Trichy, Tamil Nadu, India

\begin{abstract}
How to cite this paper: J Jose Prabhu "A Study of Community Entrepreneurship Development Research: A Resource of Clarification and Forecast" Published in International Journal of Trend in Scientific Research and Development (ijtsrd), ISSN: 24566470, Volume-3 | Issue-3, April 2019, pp.264-266, URL: http://www.ijtsrd.co $\mathrm{m} /$ papers/ijtsrd 217 41.pdf

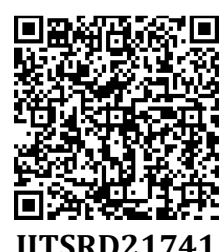

Copyright (C) 2019 by author(s) and International Journal of Trend in Scientific Research and Development Journal. This is an Open Access article distributed under the terms of the Creative Commons

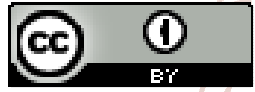
Attribution License (CC BY 4.0) (http://creativecommons.org/licenses/ by/4.0)

\section{INTRODUCTION}

As beginning and dealing with an independent company implies both social and financial hazard taking so is building a powerful community social network just as a monetary undertaking. Such a community is a most imperative setting for entrepreneurship.

While innovative marvels went for financial advancement have gotten a lot of academic consideration, entrepreneurship as a procedure to encourage social and community development has as of late pulled in light of a legitimate concern for specialists (Johnstone, H., \& Lionais, D. (2004). Like business enterprise in its initial days as a field of academic undertaking, community business investigate is still to a great extent marvel driven. Existing most investigations are commonly founded on recounted proof or contextual investigations, applying assorted research structures and techniques and presenting bits of knowledge from different controls. Like business enterprise, which even today comes up short on a binding together worldview (Welter, F. (2011). the term "social business" has taken on an assortment of implications (Dees, 1998).

This research of community entrepreneurship is still inadequately characterized and its limits to different fields of study stay fluffy. While to some this may give off an impression of being an issue, we consider it to be a one of a kind open door for specialists from various fields and teaches, for example, business enterprise, humanism and authoritative hypothesis, to test and reexamine focal ideas and presumptions. This article plans to uncover the center of community entrepreneurship so as to direct future research. Our fundamental reason is that if community entrepreneurship is to end up an organized field of research, an exertion must be made to clear up and characterize key ideas and develops. To this end, we draw on handy instances of community entrepreneurship to recognize and expand on the fundamental segments.

While the perspective on community entrepreneurship set forward in this article is a long way from complete, we consider it to be a critical initial step to upgrade our hypothetical comprehension of the marvel and encourage future research. We fight, with Kwon, S. W., Heflin, C., \& Ruef, M. (2013) that a decent hypothesis clarifies, predicts, and pleases. This article speaks to a push to stimulate look into that goes past spell binding investigations to understand the guarantee of community entrepreneurship as a source of clarification, forecast, and happiness.

The role of community foundation:

Today, in many parts of our country, we face a breakdown of community. An excessive number of our inward urban communities appear to be torn from inside and surrendered from without. Dislodged laborers legitimately stress over 
their prospects while such a large number of our childhood falter among lack of concern and outrage. The issues that plague our general public are significant and complex. There are no straightforward arrangements. Entrepreneurship is absolutely not a panacea, yet I am persuaded that it is one successful and demonstrated approach to give " personality, a feeling of having a place, a proportion of security." at the end of the day, it can add to the cheerful and reestablishing procedure of structure network.

Entrepreneurship holds a mystery weapon against lack of concern and outrage. It exhibits a secret weapon for any individual who needs to construct community. Entrepreneurship visionaries are ingrained confident people! They for the most part don't have a clue what they can't do. This idealism, this faith in the conceivable, is an astoundingly intense asset for structure community.

Psychologist Martin Seligman in his exemplary book, Learned Optimism, did earth shattering work on positive thinking and achievement. He observed that discouraged individuals will in general be more sensible than idealistic ones. Also, positive thinkers, notwithstanding when their happiness is unjustifiable, achieve more. The more troublesome the undertaking and the more noteworthy the weight, the more imperative positive thinking progressed toward becoming to the accomplishment of any undertaking.

Grubb, W. N et al (1997). Each business person trusts that his or her organization will succeed. No business visionary ever predicts disappointment. Consider that. Each business visionary really trusts that the future will be superior to the past and will unquestionably enhance the present. That kind of hopefulness is a power for community building that we have to capitalize on.

\section{On the concept of community entrepreneurship:}

This article embarks to illustrate the importance of community entrepreneurship so as to encourage further research. Expanding on set up research in entrepreneurship and late research on community entrepreneurship, we propose a working meaning of the idea. We see community entrepreneurship extensively, as a procedure including the imaginative use and mix of assets to seek after chances to catalyze social change or potentially address social and community needs.

Meanings of entrepreneurial phenomena are not really ready to catch the entire picture. The definition offered in this article intends to mirror a portion of our essential presumptions. To begin with, we see community entrepreneurship as a procedure of making an incentive by joining assets in new ways. Second, these asset blends are expected basically to investigate and abuse chances to make social incentive by stimulating social change or meeting social and community needs. Furthermore, third, when seen as a procedure, community entrepreneurship includes the offering of administrations and items however can likewise allude to the formation of new associations. Imperatively, social enterprise, as saw in this article, can happen similarly well in another association or in a set up association, Lyons, T. S., Alter, T. R., Audretsch, D., \& Augustine, D. (2012).where it might be marked " community entrepreneurship and business undertaking". Like enterprise endeavor in the business area, network business endeavor can allude to either new pursuit creation or pioneering process advancement. The hierarchical setting in which community entrepreneurship happens, i.e., recently made or set up associations, separates it from other all the more inexactly organized activities went for social and community change, for example, extremist developments.
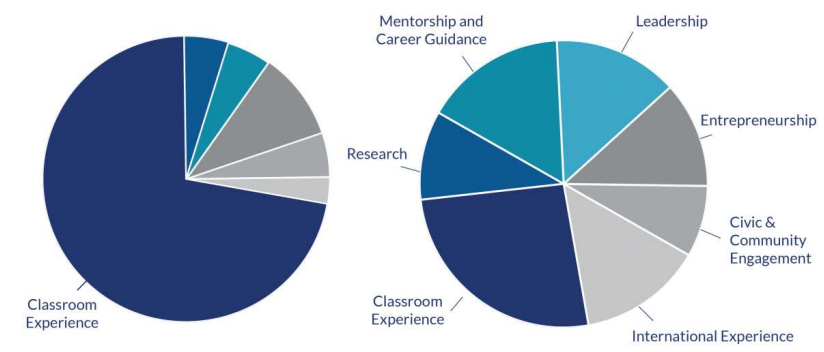

Source: V2C2 - Community Development

Distinctive features of community entrepreneurship:

Through their special contributions of new goods and services, entrepreneurs beak away from custom and in a roundabout way encourage opportunity by decreasing trust on old frameworks and advances. This outcomes in an improved personal satisfaction, improved confidence and more noteworthy monetary opportunity.

For a progressively contemporary model, cell phones and applications have upset work and play over the globe. Cell phones are not select to rich nations or individuals either. As the development of China's cell phone market and its cell phone industry appears, innovative business will have significant, enduring effects on the whole human race.

In addition, the globalization of innovation implies business visionaries in lesser-created nations approach indistinguishable instruments from their partners in more extravagant nations Johannisson, B. (1990). They additionally have the upside of a lower typical cost for basic items, so a youthful business visionary from an immature nation can take on the might of a multi-million-dollar existing item from a created nation.

\section{Here are 5 benefits of having or joining a professional community for entrepreneurs:}

1. Learning from each other's mistakes

2. Exchanging tips or recommendation of the trade

3. Passing on Informative knowledge

4. Making connections and building associates

5. Learning new business skills with community and social entrepreneurship qualities.

\section{Conclusion and Recommendations:}

The goal of this article has been to excite scholarly interest for community entrepreneurship. We view community entrepreneurship as an especially energizing and productive research point and it is our expectation that this article will present to us a bit nearer toward legitimizing and motivating social enterprise as a way to make social and monetary esteem and as a field of research.

The working meaning of community entrepreneurship set forward in this article is expected to encourage an increasingly itemized examination of the fundamental segments of community entrepreneurship, to be specific the social component and the pioneering component. We recommended that further observational and theoretical 
work is expected to set up an extensive picture of community entrepreneurship.

Huge numbers of the issues we have raised in this article are run of the mill of any developing field of research: the need to attract limits in order to delimit scope and clear up whether it truly is a free field of research, and the need to recognize the diverse dimensions of examination, orders and literary works. To finish up, we will expound on points and issues we think about imperative so as to propel our comprehension of community entrepreneurship: community entrepreneurship as a free field of research, evaluating social execution and sway, and elucidating the job of embeddedness.

Likely one the most questionable issues is whether community entrepreneurship is an autonomous field of research. Numerous examinations on network business enterprise have embraced ideas and wording utilized in the built up business writing. Does this infer community entrepreneurship is a sub-class of entrepreneurship in which the community setting gives another and strange setting in which to study and test pioneering marvels? Durkin. C et al (2016) In this article, we have endeavored to recognize the unmistakable area of community entrepreneurship.

We have more than once accentuated that community entrepreneurship takes on various structures, dependent upon economic and social conditions. Peredo, A. M et al (2006). Put in an unexpected way, we indicated the significance of the idea of embeddedness to the investigation of community entrepreneurship. A promising territory of research lies in looking at the empowering or potentially obliging impacts of embeddedness. An abnormal state of embeddedness may hinder the rise of activities went for social changes especially when those activities include changing the principles of the diversion. This offers an intriguing extra conversation starter: expecting that community entrepreneurship includes different stages.

\section{References:}

[1] Johnstone, H., \& Lionais, D. (2004). Depleted communities and community business entrepreneurship: revaluing space through place. Entrepreneurship \& Regional Development, 16(3), 217-233.

[2] Welter, F. (2011). Contextualizing entrepreneurshipconceptual challenges and ways forward. Entrepreneurship theory and Practice, 35(1), 165-184.

[3] Kwon, S. W., Heflin, C., \& Ruef, M. (2013). Community social capital and entrepreneurship. American Sociological Review, 78(6), 980-1008.

[4] Lyons, T. S., Alter, T. R., Audretsch, D., \& Augustine, D. (2012). Entrepreneurship and community: The next frontier of entrepreneurship inquiry. Entrepreneurship Research Journal, 2(1).

[5] Grubb, W. N., Badway, N., Bell, D., Bragg, D., \& Russman, M. (1997). Workforce, Economic, and Community Development. The Changing Landscape of the Entrepreneurial Community College.

[6] Peredo, A. M., \& McLean, M. (2006). Social entrepreneurship: A critical review of the concept. Journal of world business, 41(1), 56-65.

[7] Johannisson, B. (1990). Community entrepreneurshipcases and conceptualization. Entrepreneurship \& Regional Development, 2(1), 71-88.

[8] Durkin, C., \& Gunn, R. (Eds.). (2016). Social entrepreneurship: A skills approach. Policy Press. 